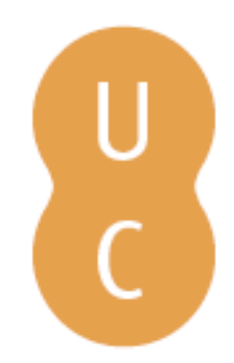

\title{
pompalina
}

\section{Cfd study of effect of water drop by aerial firefighting to protect forest fire growth}

Autor(es): $\quad$ Satoh, Koyu; Viegas, Domingos; Liu, Naian; Xie, Xiaodong; Tu, Ran

Publicado por: Imprensa da Universidade de Coimbra

URL

persistente: URI:http://hdl.handle.net/10316.2/44556

DOI: $\quad$ DOI:https://doi.org/10.14195/978-989-26-16-506_39

Accessed : $\quad$ 26-Apr-2023 11:34:13

A navegação consulta e descarregamento dos títulos inseridos nas Bibliotecas Digitais UC Digitalis, UC Pombalina e UC Impactum, pressupõem a aceitação plena e sem reservas dos Termos e Condições de Uso destas Bibliotecas Digitais, disponíveis em https://digitalis.uc.pt/pt-pt/termos.

Conforme exposto nos referidos Termos e Condições de Uso, o descarregamento de títulos de acesso restrito requer uma licença válida de autorização devendo o utilizador aceder ao(s) documento(s) a partir de um endereço de IP da instituição detentora da supramencionada licença.

Ao utilizador é apenas permitido o descarregamento para uso pessoal, pelo que o emprego do(s) título(s) descarregado(s) para outro fim, designadamente comercial, carece de autorização do respetivo autor ou editor da obra.

Na medida em que todas as obras da UC Digitalis se encontram protegidas pelo Código do Direito de Autor e Direitos Conexos e demais legislação aplicável, toda a cópia, parcial ou total, deste documento, nos casos em que é legalmente admitida, deverá conter ou fazer-se acompanhar por este aviso.

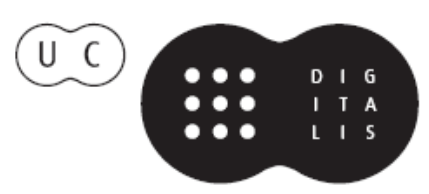




\section{ADVANCES IN}

\section{FOREST FIRE RESEARCH}

\section{8}

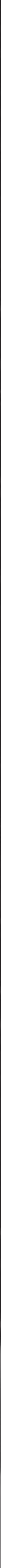




\title{
Cfd study of effect of water drop by aerial firefighting to protect forest fire growth
}

\author{
Koyu Satoh ${ }^{1 *}$; Domingos Viegas ${ }^{1}$; Naian $\mathrm{Liu}^{2}$; Xiaodong Xie ${ }^{2}$; Ran $\mathrm{Tu}^{3}$ \\ ${ }^{1}$ University of Coimbra, Coimbra 3000-370, Portugal. \{CF60420@ gmail.com*\} \\ ${ }^{2}$ University of Science and Technology of China, 96 Jinzhai Road, Hefei, Anhui 230026, China, \\ \{liunai@ustc.edu.cn\} \\ ${ }^{3}$ Huaqiao University, Xiamen, Fujian 361021, \{turan@hqu.edu.cn\}
}

\begin{abstract}
Wildfires destroy the natural environment, cause property damages and cause victims, therefore great research effort is dedicated to improve protection against wildfires. As fire growth depends on many parameters to examine behavior relevant to fire protection methods systematically, we used CFD simulations to analyze the role of aerial fire-fighting. CFD simulations of the fire spread in relation to the water drop effect in aerial fire-fighting were done using the $(15 \times 15)$ fuel array in windy conditions. A single fuel cell is $8 \mathrm{~m} \times 8 \mathrm{~m} \times 2 \mathrm{~m}$, varying the space distance between the adjacent fuel cells. The water drop effect is examined as a function of the heat release rate, varying the wind speed. The results of our previous studies showed that it is difficult to extinguish the burning area in wildfires by directly dropping water over the flames and also it is less effective to drop water in the fringe areas of burning fires parallel to the wind direction. Therefore, the way selected in this study is to drop water in the downwind area slightly away from the fire front, making a water belt to reduce the radiative heat transfer. However, if the fuel distributes densely, even the water belt dropped in the area of $20 \mathrm{~m} \times 60 \mathrm{~m}$ may not sufficient to stop the fire spread, since the fires may detour both sides of the water belt or the fires jump over the water belt. However, water dropped belts are very effective to delay the fire spreading speed. If the space distance between adjacent fuel cells is larger than $2 \mathrm{~m}$, the water belt can protect or highly delay the fire spread. One problem is the amount of water to realize such a water belt to stop the fire spread, since helicopters carry too few water and it is dangerous for helicopters to fly in the hot and smoky air. Large aircrafts carrying large amount of water are needed to make such a large water belt.
\end{abstract}

Keywords: CFD Study, Forest Fire, Aerial Firefighting, Water Drop, Fire Spreading Speed, Wind speed

\section{Introduction}

Wildfires destroy property, cause victims and emit large quantities of greenhouse gases, which may contribute to the climate change and enhance large-scale wildfires. Over recent years wildfires are globally increasing. Therefore, many researches (Viegas, 2006; Finney, 2003; Abatzoglou et al, 2018; Liu et al, 2007) have been made to protect and mitigate the damages by forest fires, examining the fire growth behavior. As the fire spread depends on many parameters and so it is difficult to examine the fire spread behavior in relation to the fire protection methods systematically, we used CFD simulation methods. The authors (Satoh et al, 2000; Satoh et al, 2003; Satoh et al, 2005; Satoh et al, 2008; McGrattan et al, 2000) have studied the fire protection methods in relation to the wind speed affecting the fire spread, together with the water drop effect by an aerial fire-fighting. The objective of this study is to examine the water drop effect upon the fire protection, particularly how large area is needed to protect the fire spread by the aerial water drop, using CFD simulation methods based on FDS by NIST (Floyd et al, 2006; McGrattan et al, 2001). CFD simulations of the fire spread are done using the (15 $\mathrm{x} 15$ ) fuel arrays. The results of our previous studies (Satoh et al, 2000; Satoh et al, 2005) showed that it is difficult to extinguish the burning area by directly dropping water over the fire and also it is less effect to drop water in the fringe areas of burning fires parallel to the wind direction. 
Therefore, the way selected in this study is to drop water in the downwind area, slightly away from the fire front, making a water belt to reduce the radiative and convective heat transfer.

\section{Schematics and Simulation Method}

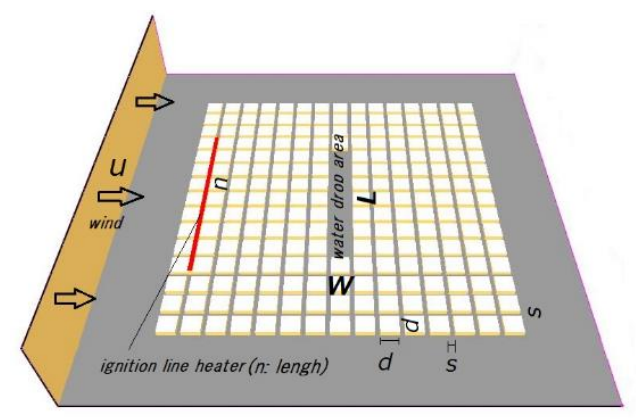

Figure 1 - Schematics of $(15 x$ 15) fuels in CFD simulations

Figure 1 shows the schematics of the $(15 \times 15)$ array with an equal apace distance $(s)$ between adjacent square fuels. The space distance $(s)$ varies from $0 \mathrm{~m}$ to $4 \mathrm{~m}$. The dimensions of each fuel cell are $d \times d \times h$, where $d$ is the length and $h$ is the height of each square fuel cell. This study deals only with one case of $d=8 \mathrm{~m}$ and $h=2 \mathrm{~m}$. Other configurations will be studied in the future. At one vertical boundary, uniform wind blows with the wind speed of $u$. An ignition line heater with the length of $n$ and the width of $1 \mathrm{~m}$ or a square $(2 \mathrm{~m} \times 2 \mathrm{~m})$ heater is used, giving the heat release rate per area $(q)$, but no fire brands are considered. The relationship between the total heat release rate $(Q)$ and the wind speed $(u)$, varying the ignition heat source length $(n)$ and the space distance $(s)$, under the water dropped conditions in the aerial fire-fighting or no water dropped. Here, "water dropped area" means no fuel exists in one fuel cell and the water dropped area has the width $W$ (in the wind direction) and the length $L$ (perpendicular to the wind direction), locating at $18 \mathrm{~m}$ (for small scale fires) to $72 \mathrm{~m}$ (for larger scale fires) apart from the ignition heat source. In this simulation study, using the software FDS by NIST (McGrattan et al, 2000; Floyd et al, 2006; McGrattan et al, 2001), the combustion of fuels ignited by a heater is based on a mixing-controlled chemical reaction model. After the reaction of fuel and oxygen, $\mathrm{CO}_{2}$ and soot are produced, together with the convective heat, conductive heat and radiative heat affecting the fuel combustion in the downwind area. Radiative heat transfer is based on the solution of the radiation transport equation for a gray gas and the details are found in the user's guide of FDS (McGrattan et al, 2001). Difficulty was the choice of the fuel material. As a fuel, several materials are tested in the preliminary simulations, but the fuel in this study has no porous structure like real forest materials. Simulations of some whole solid materials with the size of $8 \mathrm{~m} \times 8 \mathrm{~m} \times 2 \mathrm{~m}$ needed so long computing time and some soft materials burned out too short. Thus, the "black PMMA" shown in the user's guide of FDS (Floyd et al, 2006), having the heat of combustion of $25200 \mathrm{~kJ} / \mathrm{kg}$, the density of $1100 \mathrm{~kg} / \mathrm{m}^{3}$ and the conductivity of $0.20 \mathrm{~W} /(\mathrm{m} \mathrm{K})$, was used in this study. Except for the ground, all other boundaries are open, but a uniform wind is blowing in one vertical boundary. The four additional areas around the fuel array with the width of $30 \mathrm{~m}$ as shown in Figure 1 are added, so the total ground area is $180 \mathrm{~m} \times 180 \mathrm{~m}$ for $s=0 \mathrm{~m}$ and $240 \mathrm{~m} \times 240 \mathrm{~m}$ for $s=4 \mathrm{~m}$. Grid sizes used in the simulations largely affect the simulation results. However, the maximum number of grid cells used in the computations is limited due to the computer memory limit and the total computing time. Therefore, one uniform grid cell size of $0.5 \mathrm{~m} \times 0.5 \mathrm{~m} \times 0.5 \mathrm{~m}$ is used in this simulation, where one case computation reaching the whole area combustion during several thousand seconds needed two or three months by a single personal computer. More than 200 cases of simulations, varying the wind speed and the water drop area, were done systematically. 


\section{Results}

\subsection{Behavior of fire spread and effect of water drop to protect fire spread}

The fire spread behavior is highly affected by the distance between fuel cells. Therefore, we investigated the relationship between the total heat release rate produced by the fuel combustion $(Q)$ and the space distance $(s)$, with varying wind speed $(u)$. Preliminary simulations showed that the heat release rate per area $(q)$ of ignition heat source, between $q=1500$ and $2500 \mathrm{~kW} / \mathrm{m}^{2}$, against the fire spreading behavior had only small effect upon the fuel combustion and the fire spreading patterns. However, the heating time had considerable effect on the fire spreading patterns, since the ignition source assists it. Therefore we employed values of the ignition heat source of $q=2000 \mathrm{~kW} / \mathrm{m}^{2}$, heating time $t=1000 \mathrm{sec}$ and the size of ignition source is $(1 \mathrm{~m} \times n(\mathrm{~m}))$ or $(2 \mathrm{~m} \times 2 \mathrm{~m})$.

\subsubsection{Case of $s=0 m$ (no space between fuel cells) and $n=2 m$}

Figure 2 shows the fire spreading profiles at $u=2 \mathrm{~m} / \mathrm{s}$ and $10 \mathrm{~m} / \mathrm{s}$, where there is no space between fuel cells and no water is dropped, keeping the ignition source size at $(2 \mathrm{~m} \times 2 \mathrm{~m})$ and the heat release rate per area $q=2000 \mathrm{~kW} / \mathrm{m}^{2}$. In the case of $u=2 \mathrm{~m} / \mathrm{s}$, the fire spreading pattern of fuels with no spaces becomes round and spreading into the lateral direction, too, but in the case of $u=10 \mathrm{~m} / \mathrm{s}$ the fire is spreading mainly in the downwind direction.

(A) $u=2 \mathrm{~m} / \mathrm{s}$,

(1) $t=504 \mathrm{~s}$

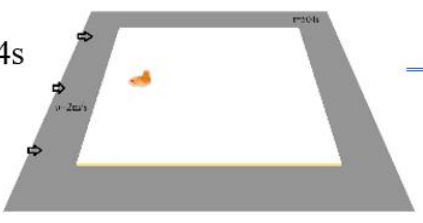

(2)

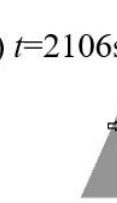

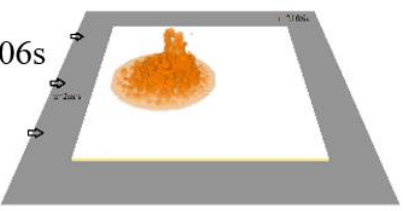

(3)

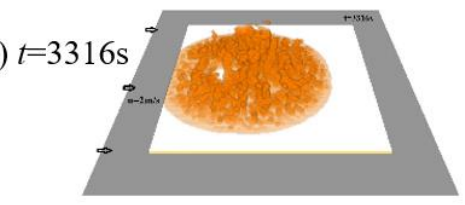

(B) $u=10 \mathrm{~m} / \mathrm{s}$

(1) $t=400 \mathrm{~s}$

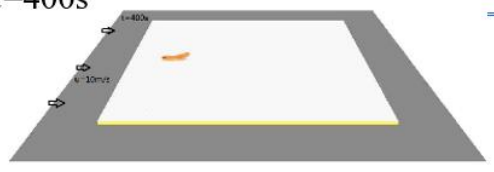

(2)

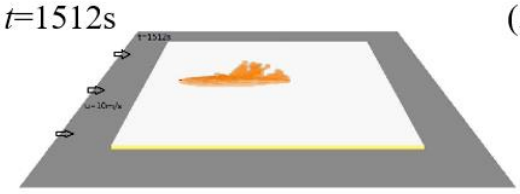

(3) $t=1912 \mathrm{~s}$

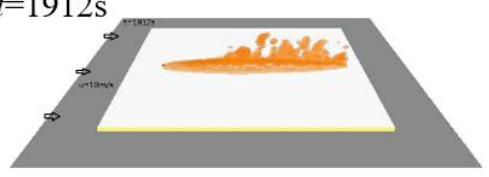

Figure 2 - Fire spreading profile of the case at $s=0 m$, with no water drop.

Next, the effect of water drop in the downwind area to limit the fire spread is examined, comparing with no water drop case, using the ignition heat of $(2 \mathrm{~m} \times 2 \mathrm{~m})$ under the wind speeds of $u=2 \mathrm{~m} / \mathrm{s}$ and $4 \mathrm{~m} / \mathrm{s}$. Figure 3 shows the total heat release rate as a function of time for Case (A) $s=0 \mathrm{~m}$ and $u=2 \mathrm{~m} / \mathrm{s}$ and Case (B) $s=0 \mathrm{~m}$ and $u=4 \mathrm{~m} / \mathrm{s}$. Figure 4 shows the fire spreading patterns for Cases (A) and (B). As shown in Figure 3, the heat release rate $(Q)$ begins to increase suddenly and rapidly, which may be dangerous for firefighters. The water dropped areas in Figure 3(A) are ( $W=10 \mathrm{~m} \times L=20 \mathrm{~m})$ and $(W=20 \mathrm{~m}$ $\mathrm{x} L=40 \mathrm{~m})$. In the case of water dropped area of $(10 \mathrm{~m} \times 20 \mathrm{~m})$, the fire can jump over the water belt and the fire can spread in the downwind area, as shown in Figure 3(C)-(2), although the fire spread is highly weakened. The water drop belt of $(20 \mathrm{~m} \times 40 \mathrm{~m})$ is effective to stop the fire spread, where the fire cannot jump over the belt with the width of $W=20 \mathrm{~m}$ and also cannot detour both sides of the belt, since the delay time is too long, the radiative heat transfer becomes weak and the spreading fires gradually burn out. Therefore, the water dropped belt of $(20 \mathrm{~m} \times 40 \mathrm{~m})$ in the downwind of the fire caused by a small ignition heat source in a weak wind can stop the fire spread. 
(A)

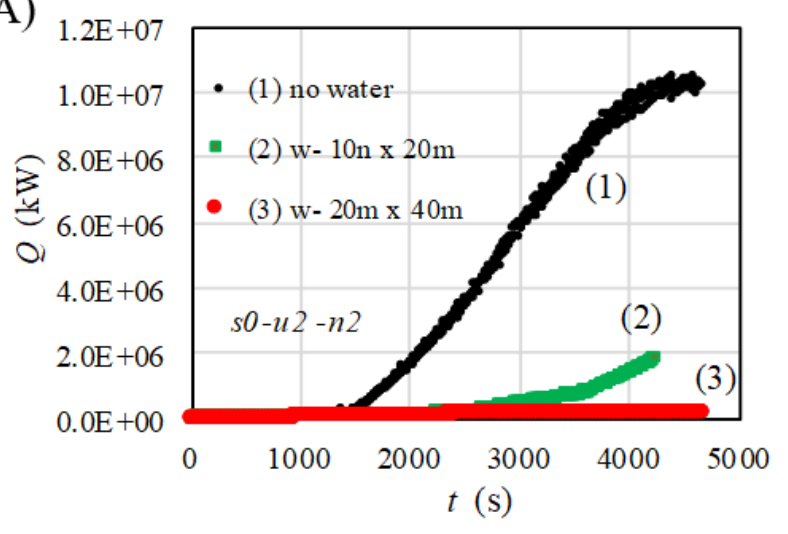

(B)

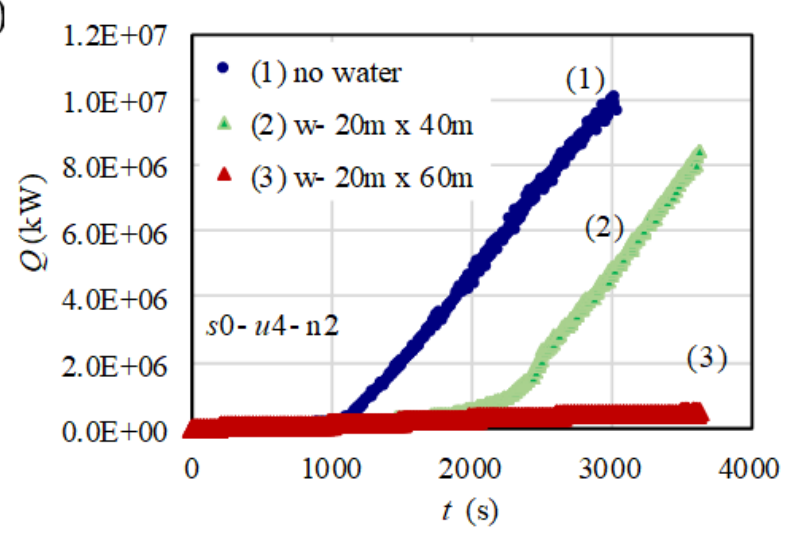

(C) $s=0 \mathrm{~m}, u=2 \mathrm{~m} / \mathrm{s}, n=2 \mathrm{~m}$

(1) no water,

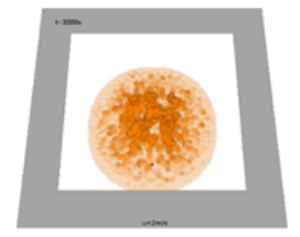

$t=3000 \mathrm{~s}$,

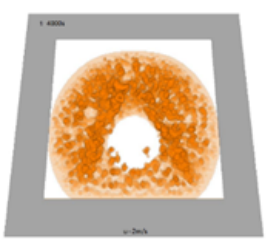

$t=4000$ s,
(2) water drop (10m x 20m),

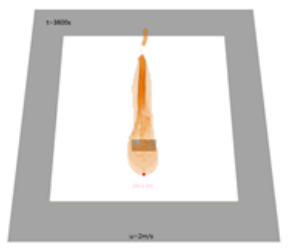

$t=3400 \mathrm{~s}$

(3) water drop (20m x 40m)

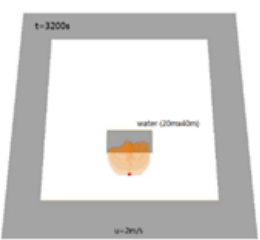

$t=3200 \mathrm{~s}$,

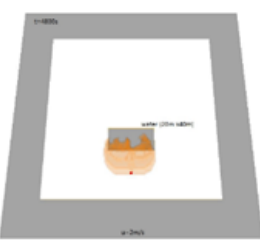

$t=4800 \mathrm{~s}$

(D) $s=0 \mathrm{~m}, u=4 \mathrm{~m} / \mathrm{s}, n=2 \mathrm{~m}$

(1) no water,

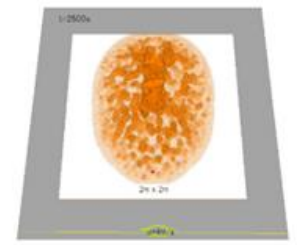

$t=2500 \mathrm{~s}$,
(2) water drop (20 m x 40m),

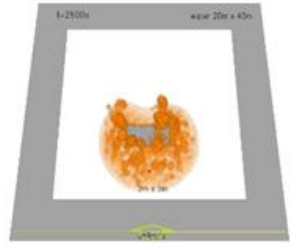

$t=2500 \mathrm{~s}$,

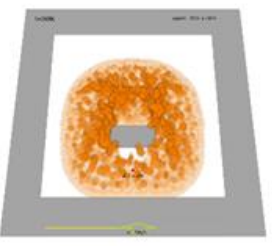

$t=3400$ s,
(3) water drop (20 m x 60m)

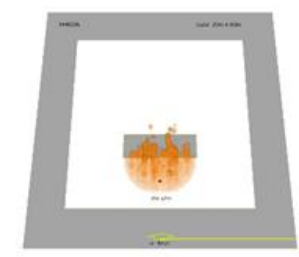

$t=4500 \mathrm{~s}$

Figure 3 - (A) and (B) total heat release of fuels as a function of time, $(C)$ and (D) burning profiles, comparing water drop effect with no water drop, (A) and $(C): s=0 m, u=2 m / s, n=2 m,(B)$ and $(D): s=0 m, u=4 m / s, n=2 m$

For the case of $u=4 \mathrm{~m} / \mathrm{s}$ at $s=0 \mathrm{~m}$, Figure 3(B) shows the water drop effect in the area of (20m x 40m) and $(20 \mathrm{~m} \times 60 \mathrm{~m})$ comparing with the case of no water drop. The case of water drop of $(20 \mathrm{~m} \times 40 \mathrm{~m})$ cannot allow the fire jumping over the water belt, but cannot stop the fire spread, since the fire soon begins to detour both sides of the water belt and spreads into the downwind area, which can however delay the fire spreading time. The water drop of $(20 \mathrm{~m} \times 60 \mathrm{~m})$ in the downwind area can stop the fire spread, as shown in Figure 3(D)-3, but gradually begins to detour both sides of the water dropped area, extending toward the downwind direction. Therefore, a much longer water belt may be needed to stop or to delay the fire spread much more. Extending the wind up to $12 \mathrm{~m} / \mathrm{s}$ and the water dropped area up to $80 \mathrm{~m}$, the effect of water dropped area against the fire spread is examined. Figure 4 shows the relationship between the total heat release rate of fuels and time for $s=0 \mathrm{~m}$ and $u=8 \mathrm{~m} / \mathrm{s}$, varying the water dropped area. The heat release rates quickly increase at a time when the fire begins to detour, which we called the "critical time $\left(t_{q}\right)$ " in this paper, defined as the time when the total heat release 
rate exceeds $Q=1 \mathrm{E}+06 \mathrm{~kW}$. More critical times are examined, varying the wind speed between $u=4 \mathrm{~m} / \mathrm{s}$ and $12 \mathrm{~m} / \mathrm{s}$. Figure 5 shows the relationship between the critical time $\left(t_{q}\right)$ and the length $(L)$ of water dropped area with the width $W=20 \mathrm{~m}$, varying the wind speed. The critical time $\left(t_{q}\right)$ is linearly proportinal to the length $(L)$ of water dropped area. At the width of water belt of $W=20 \mathrm{~m}$, the fires do not jump over the water belt, but the fires can detour both sides of the water belt as shown in Figure 6 , which shows the burning profiles of fuels.

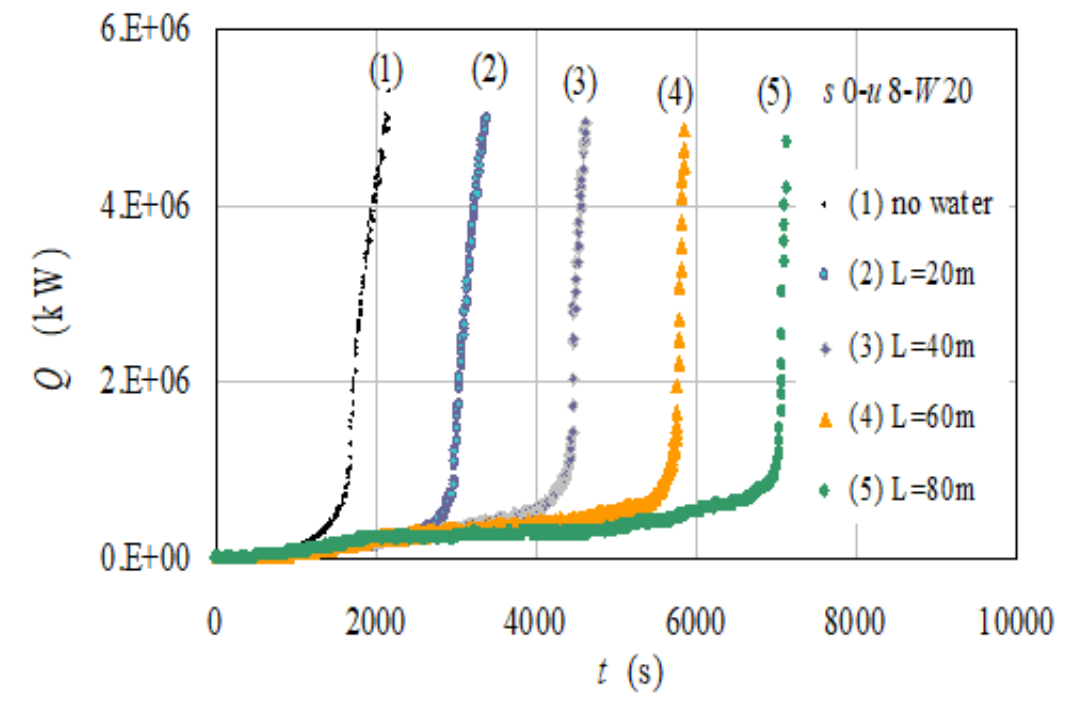

Figure 4 - Relationship between total heat release rate of fuels and time

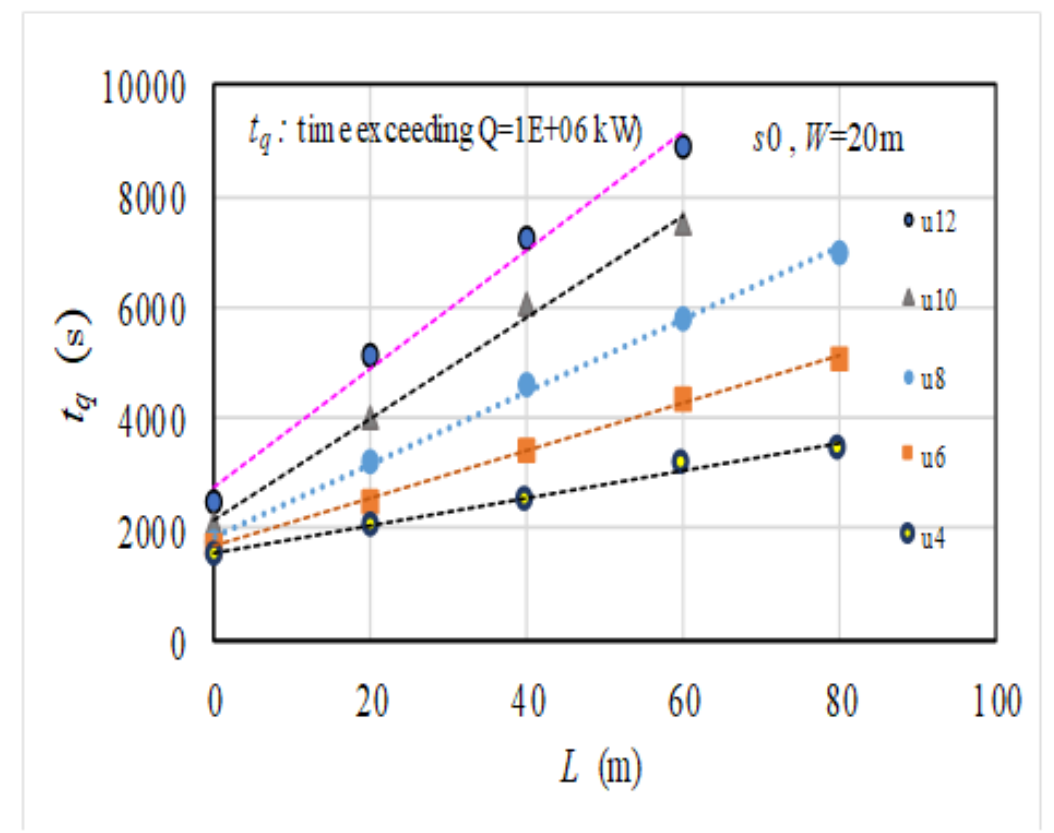

Figure 5 - Relationship between total heat release rate of fuels and heat length 
(1) No water,

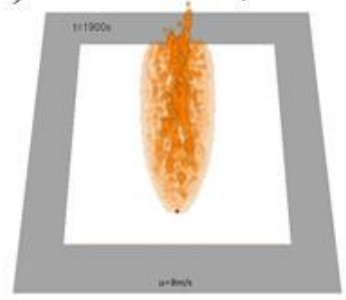

$t=1800 \mathrm{~s}$,
(2) $L=20 \mathrm{~m}$,

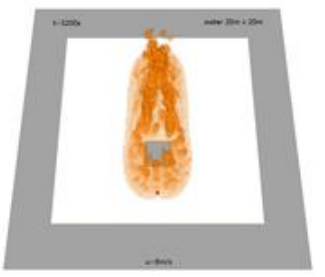

$t=3200$ s,
(3) $L=40 \mathrm{~m}$,

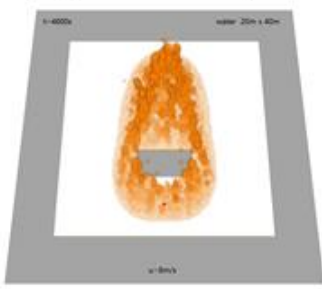

$t=4600 \mathrm{~s}$,
(4) $L=60 \mathrm{~m}$

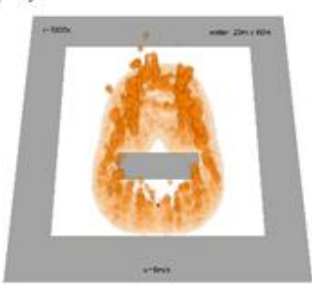

$t=5800 \mathrm{~s}$

Figure 6 - Burning profiles of fuels at $s=0 \mathrm{~m}, u=8 \mathrm{~m} / \mathrm{s}$ and $\mathrm{W}=20 \mathrm{~m}$

Table 1 shows the critical time divided by the wind speed $(u)$. Except for some cases of no water $(L=0 \mathrm{~m})$, the divided values $\left(t_{q} / u\right)$ are almost similar for each length $L$. The average values of $\left(t_{q} / u\right)$ are plotted in Figure 7, as a function of $L$. Thus, those relationships shown in Figure 5 can be correlated by the following equation:

$$
t_{q} / u=7.4 L+281
$$

Table 1 - The critical time divided by the wind speed $\left(t_{q} / u\right)$

\begin{tabular}{r|rrrrrr}
\hline$L(\mathrm{~m})$ & $u=12 \mathrm{~m} / \mathrm{s}$ & $u=10 \mathrm{~m} / \mathrm{s}$ & $u=8 \mathrm{~m} / \mathrm{s}$ & $u=6 \mathrm{~m} / \mathrm{s}$ & $u=4 \mathrm{~m} / \mathrm{s}$ & average \\
\hline 0 & 208 & 209 & 216 & 287 & 375 & 259 \\
20 & 425 & 401 & 400 & 417 & 513 & 431 \\
40 & 604 & 603 & 575 & 573 & 625 & 596 \\
60 & 742 & 752 & 725 & 725 & 788 & 746 \\
80 & & & 869 & 842 & 858 & 856 \\
\hline
\end{tabular}

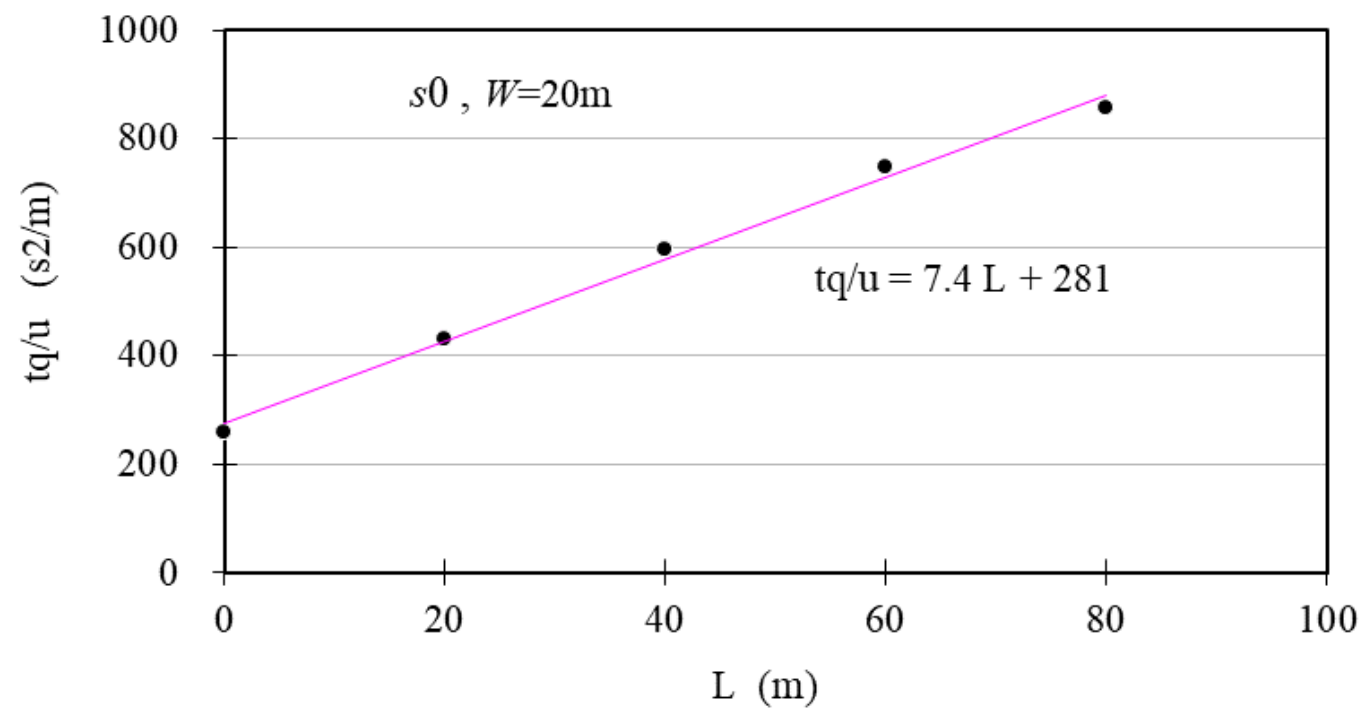

Figure 7 - Relationship between the average critical time divided by the wind speed and length of water dropped area. 


\subsubsection{Heat release rate using a line heater, $s=0 m$}

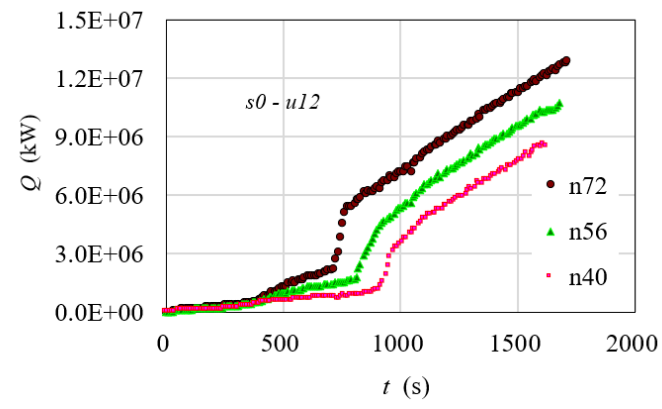

Figure 8 - Total heat release rate of fuels as a function of time, varying the length of line heater, $s=0 \mathrm{~m}, u=12 \mathrm{~m} / \mathrm{s}$

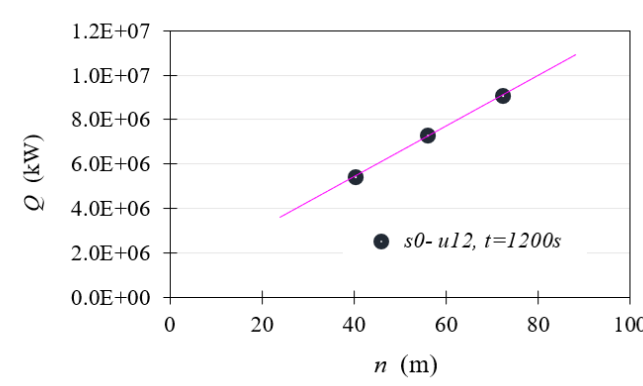

Figure 9 - Relationship between heat release rate and length of water drop area $(n)$ at $t=1200 \mathrm{sec}, s=0 \mathrm{~m}, u=12 \mathrm{~m} / \mathrm{s}$

Figure 8 shows the total heat release of fuels as a function of time, varying the length (n) of line heater, for $\mathrm{s}=0 \mathrm{~m}$ and $\mathrm{u}=12 \mathrm{~m} / \mathrm{s}$, where the relationships are parallel between 1000 to $1500 \mathrm{sec}$. The heat release rates at $\mathrm{t}=1200 \mathrm{sec}$ are plotted as a function of the ignition heat source length (n) in Figure 9, where the heat release rate is linearly proportional to the ignition heat source length. This linear relationship shown in Figure 9 between the heat release rate and the wind speed are found in many cases varying the fuel space and the ignition source length. Figure 10(A) shows the heat release rate vs. time for $\mathrm{s}=0 \mathrm{~m}, \mathrm{u}=8 \mathrm{~m} / \mathrm{s}$ and $\mathrm{u}=12 \mathrm{~m} / \mathrm{s}$ at $\mathrm{n}=72 \mathrm{~m}$ and Figure $10(\mathrm{~B})$ shows the fire spreading patterns. At $\mathrm{u}=12 \mathrm{~m} / \mathrm{s}$ and the water drop area of $\mathrm{W}=18 \mathrm{~m} \times \mathrm{L}=80 \mathrm{~m}$, the fire spread is protected at $\mathrm{t}=1200 \mathrm{sec}$, but at $\mathrm{u}=8 \mathrm{~m} / \mathrm{s}$ and the water drop area of $\mathrm{W}=16 \mathrm{~m} \times \mathrm{L}=80 \mathrm{~m}$, the fire jumped over the water drop area at $\mathrm{t}=800 \mathrm{sec}$. Fires at $\mathrm{s}=0 \mathrm{~m}$ and ignited by a long heater can spread very fast and strong. The width $\mathrm{W}=18 \mathrm{~m}$ of the water drop area is effective to protect the fire jumping over the water dropping, but fires can detour from both sides of the water drop area. Therefore, it is generally difficult to protect the fire spread at $s=0 \mathrm{~m}$, even by a large water dropped area.

(A)

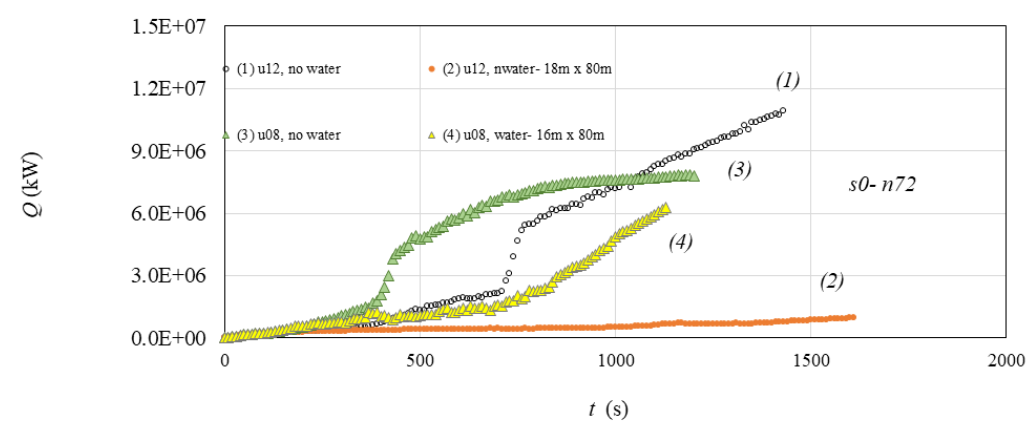

(B)

(1)

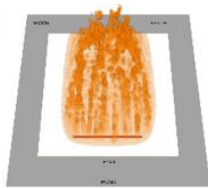

(2)

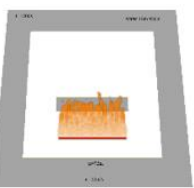

(3)

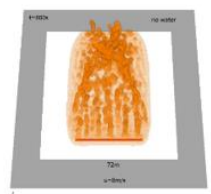

(4)

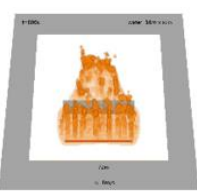

Figure 10 - (A) Relationship between heat release rate and time, (B) burning profiles at $t=800 \mathrm{~s}, \mathrm{n}=72 \mathrm{~m},(1) \mathrm{u}=12 \mathrm{~m} / \mathrm{s}$, no water, (2) $u=12 \mathrm{~m} / \mathrm{s}$, water $-W=18 \mathrm{~m} \times \mathrm{L}=80 \mathrm{~m}$, (3) $u=8 \mathrm{~m} / \mathrm{s}$, no water, (4) $u=8 \mathrm{~m} / \mathrm{s}$, water $-W=16 \mathrm{~m} \times \mathrm{L}=80 \mathrm{~m}$ 


\subsubsection{Case of $s=1 m$}

(A)

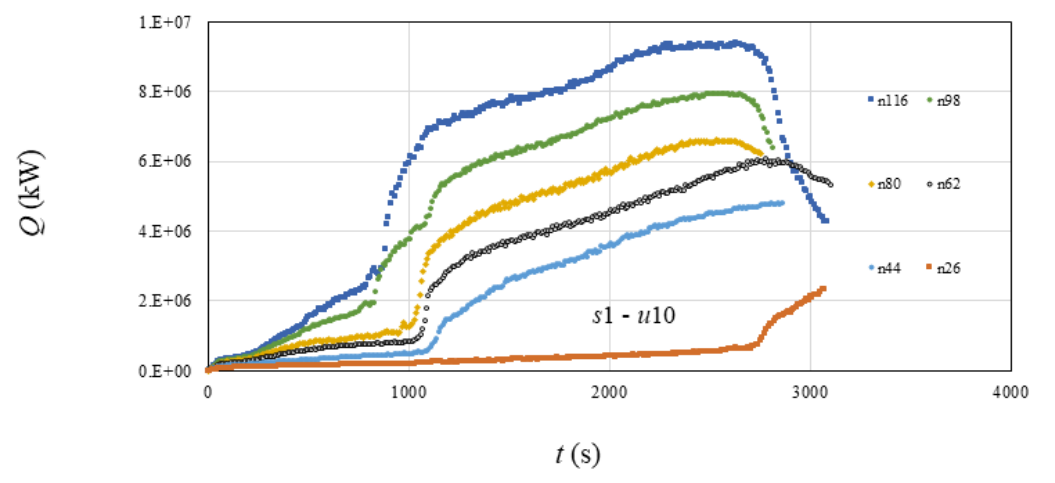

(B)

(1) $n=44 \mathrm{~m}$,

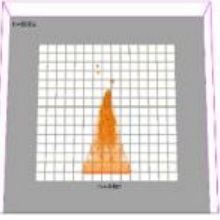

(2) $n=62 \mathrm{~m}$,

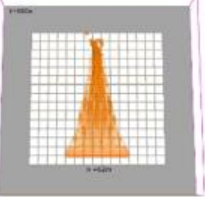

(3) $n=80 \mathrm{~m}$,

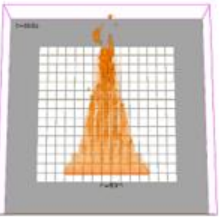

(4) $n=116 \mathrm{~m}$

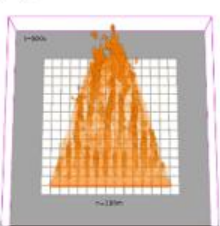

Figure 11 - (A) Relationship between heat release rate and time and (B) burning profiles of fuels at $t=800$ s, varying the ignition fire source length $(n), s=1 m, u=10 \mathrm{~m} / \mathrm{s}$.

Figure 11(A) shows the relationship between the total heat release rate and time for $s=1 \mathrm{~m}$ and $u=10 \mathrm{~m} / \mathrm{s}$, varying the ignition fire source length $(n)$. Figure 11(B) shows the burning profiles of fires. Figure 12 shows the relationship between the heat release rate and the length of water drop area $(n)$ at 1500 and 2000sec, where the heat release rate is linearly proportional to the ignition heat source length. As mentioned above, this linear relationshp between the heat release rate and the line heater length are observed in the cases of $s=2 \mathrm{~m}, 3 \mathrm{~m}$ and $4 \mathrm{~m}$.

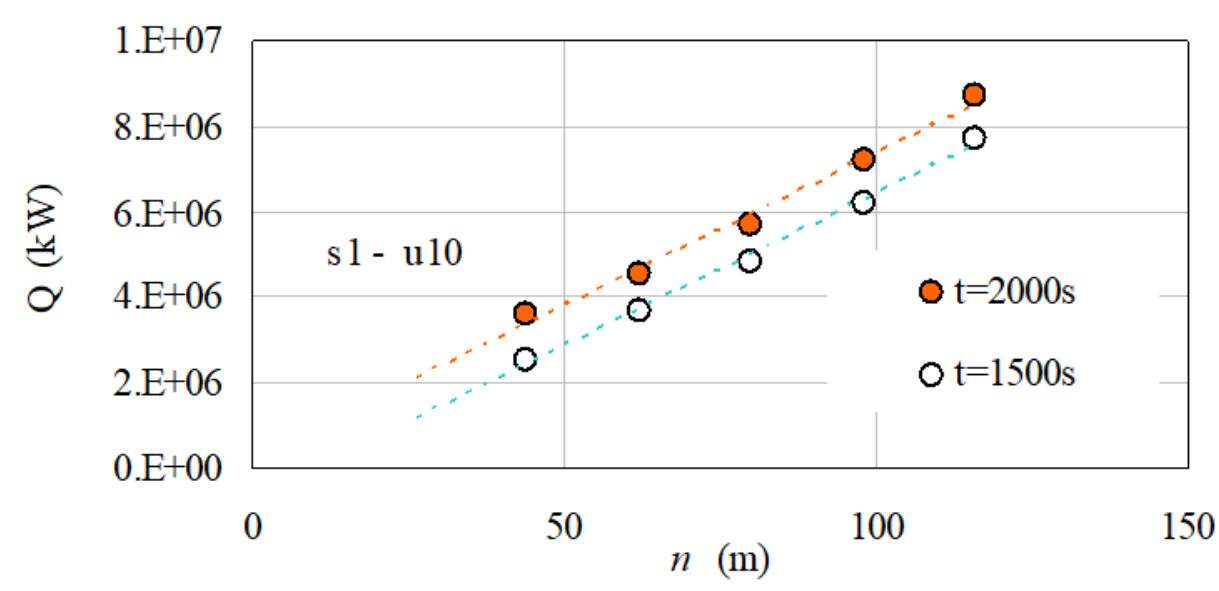

Figure 12 - Relationship between heat release rate and length of water drop area (n) at time 1500 and $2000 \mathrm{sec}, \mathrm{s}=1 \mathrm{~m}$, $u=10 \mathrm{~m} / \mathrm{s}$. 
(A)

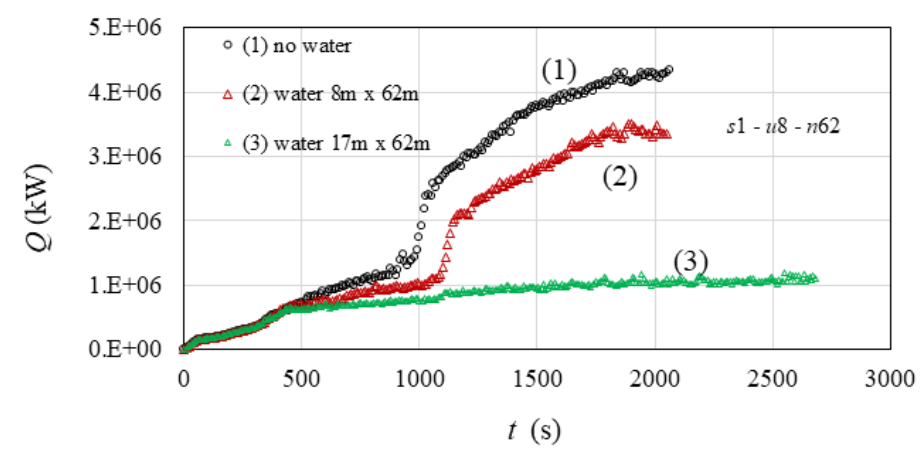

(B)

(1)

$t=1200$ s

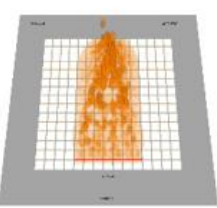

(2)

$t=1500$ s

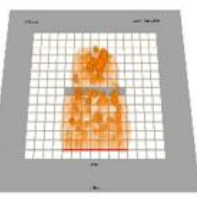

(3)

$t=2400$ s

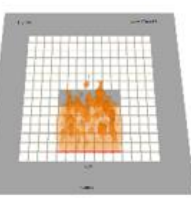

Figure 13 (A) - Relationship between heat release rate and time, (B) burning profiles of fires, for $s=1 \mathrm{~m}, u=8 \mathrm{~m} / \mathrm{s}$, $n=62 m$, (1) no water, (2) water $-W=8 m \times L=62 m$, (3) water $-W=17 m \times L=62 m$.

Figure 13(A) shows the relationship between heat release rate and time for $s=1 \mathrm{~m}$ and $u=8 \mathrm{~m} / \mathrm{s}$, comparing the effect of water drop area, keeping the ignition fire source $n=62 \mathrm{~m}$. Figure 13 (B) shows the fire spreading profiles. For $s=1 \mathrm{~m}$, the width $W=17 \mathrm{~m}$ of the water drop area is effective to protect the fire jumping over the water drop area, while the width $W=8 \mathrm{~m}$ allowed to jumping over the fire spread. Figure 14(A) shows the relationship between heat release rate and time for $s=2 \mathrm{~m}$ and $n=128 \mathrm{~m}$, warying the wind speed. Figure 14(B) shows the fire spreading profiles at $t=2100 \mathrm{~s}$, varying the wind speed. As shown in Figure 15, the heat release rates begin to increase from $u=4 \mathrm{~m} / \mathrm{s}$ and reach almost constant at $u=10 \mathrm{~m} / \mathrm{s}$. This relationship curve can be found in other cases of $s=1 \mathrm{~m}, 3 \mathrm{~m}$ and $4 \mathrm{~m}$, too.

\subsubsection{Case of $s=2 m$}

(A)

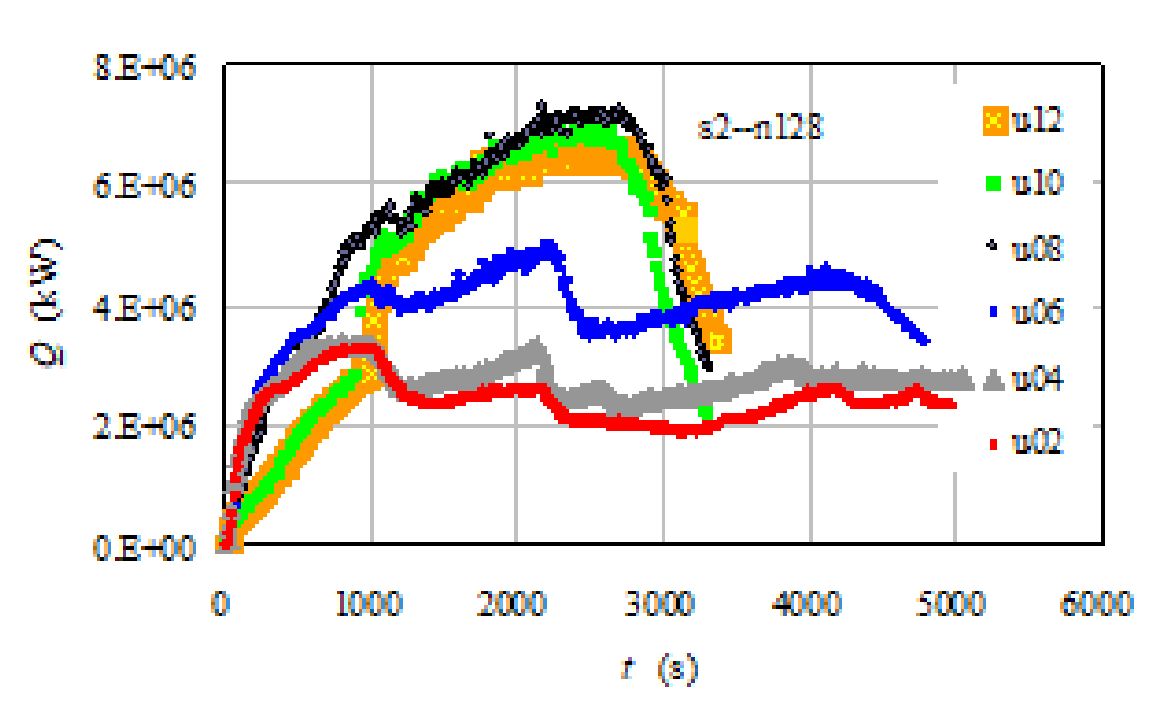


(B)
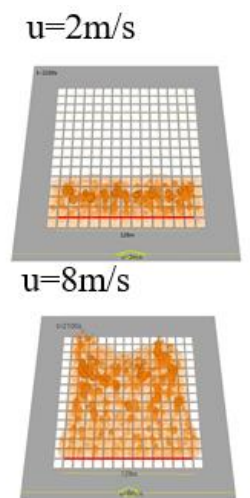

$\mathrm{u}=4 \mathrm{~m} / \mathrm{s}$

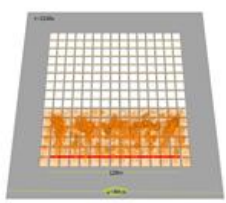

$\mathrm{u}=10 \mathrm{~m} / \mathrm{s}$

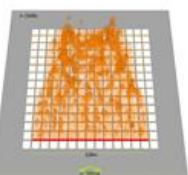

$\mathrm{u}=6 \mathrm{~m} / \mathrm{s}$

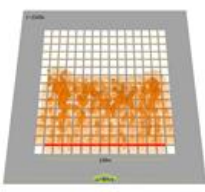

$\mathrm{u}=12 \mathrm{~m} / \mathrm{s}$

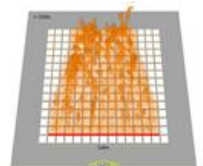

Figure 14 - (A) Relationship between heat release rate and time, (B) burning profiles of fires at $t=2100 s, s=2 m$, $n=128 \mathrm{~m}$, varying the wind speed

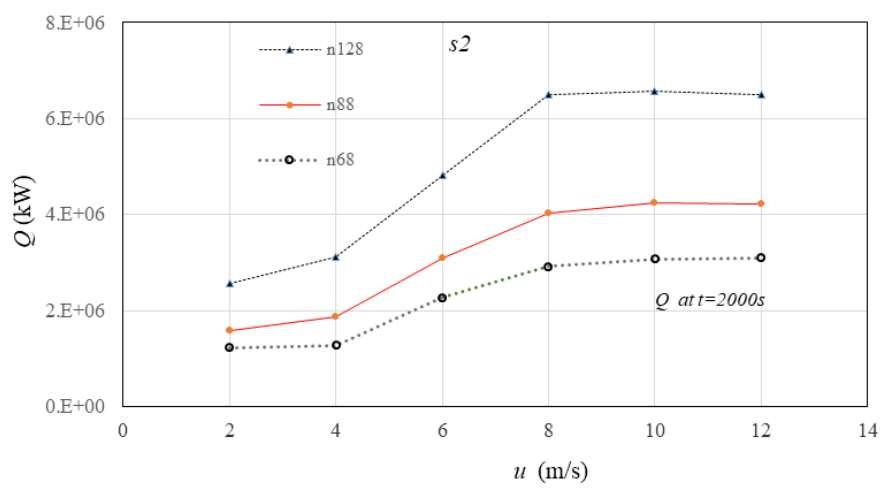

Figure 15 - Relationship between heat release rate and wind speed at $t=2000 \mathrm{sec}, \mathrm{s}=2 \mathrm{~m}$, varying the ignition source length ( $n$ )

Figure 16(A) shows the relationships between heat release rate and time for $s=2 \mathrm{~m}, \mathrm{u}=8 \mathrm{~m} / \mathrm{s}$ and $n=68 \mathrm{~m}$ and Figure 16(B) for $s=2 \mathrm{~m}, u=10 \mathrm{~m} / \mathrm{s}, n=88 \mathrm{~m}$, varying the water drop area. Figure $16(\mathrm{C})$ shows the fire spreading profiles at $t=1400 \mathrm{~s}$ and Figure $16(\mathrm{C})$ at $\mathrm{t}=1500 \mathrm{~s}$, varying the wind speed. The fire spread is protected by the water drop at $\mathrm{W}=18 \mathrm{~m} \times \mathrm{L}=68 \mathrm{~m}$, while the water drop area at $W=8 \mathrm{~m}$ cannot stop the jumping over the fire spread. Since the fires at $s=2 \mathrm{~m}$ cannot detour both sides of the water drop area, the width $W$ is important to protect the fire spread. Therefore, the water drop length $(L)$ larger than the ignition source length $(n)$ can protect the fire spread at $s=2 \mathrm{~m}$. 
(A)

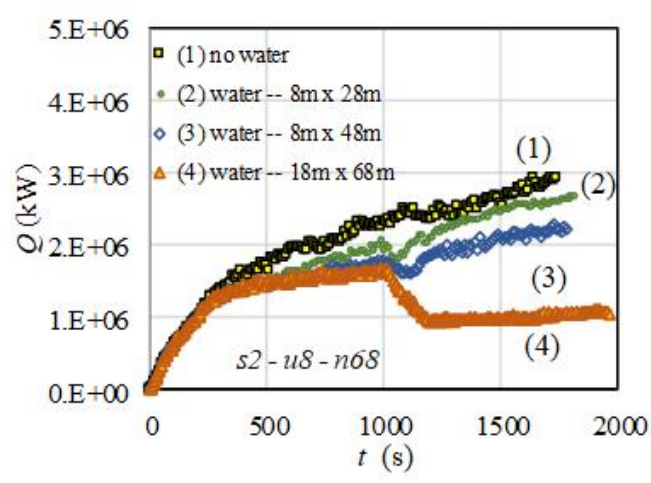

(C) no water,

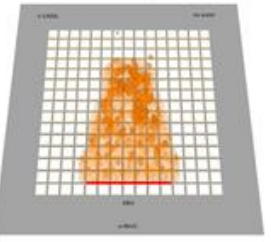

(D)

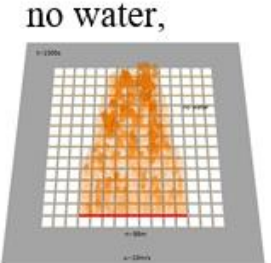

(B)

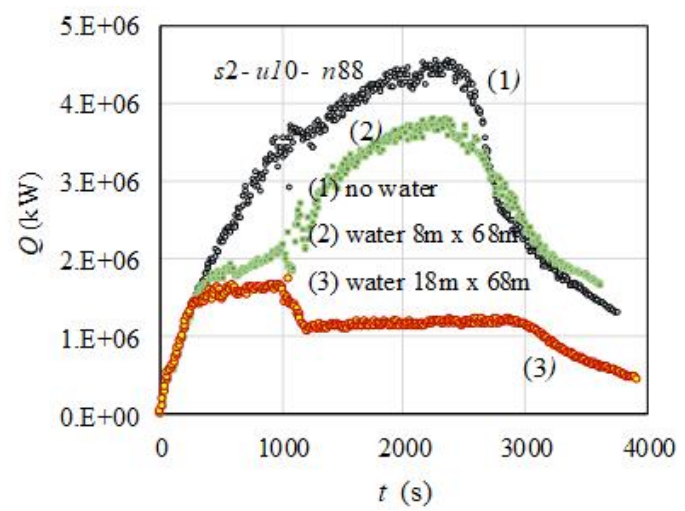

water $-8 \mathrm{~m} \times 28 \mathrm{~m}$,

water $-18 \mathrm{~m} \times 68 \mathrm{~m}$

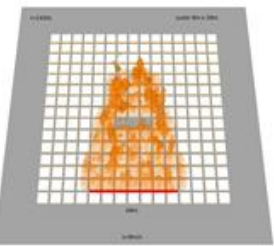

water $-8 \mathrm{~m} \times 68 \mathrm{~m}$,

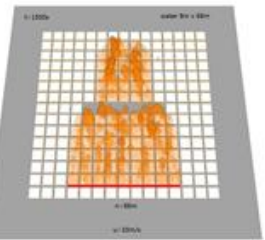

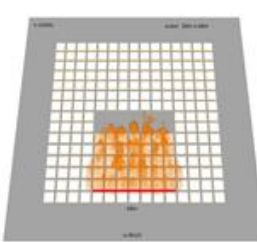

water $-18 \mathrm{~m} \mathrm{x} 68 \mathrm{~m}$

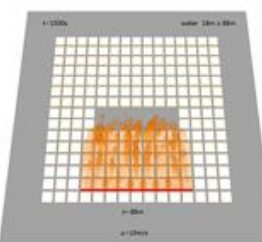

Figure 16 - (A), (B) Relationship between heat release rate and time, varying water drop area, (A) $s=2 \mathrm{~m}, u=8 \mathrm{~m} / \mathrm{s}$ and $n=68 \mathrm{~m},(B) s=2 \mathrm{~m}, u=10 \mathrm{~m} / \mathrm{s}, n=88 \mathrm{~m},(C),(D)$ burning profiles of the fuels, $(C) s=2 \mathrm{~m}, u=8 \mathrm{~m} / \mathrm{s}$ and $n=68 \mathrm{~m}, t=1400 \mathrm{~s}$,

(D) $s=2 m, u=10 \mathrm{~m} / \mathrm{s}, n=88 \mathrm{~m}, \mathrm{t}=1500 \mathrm{~s}$

\subsubsection{Cases of $s=3 m$ and $s=4 m$}

Figure 17 shows the relationship between heat release rate and time for Case (A) $s=3 \mathrm{~m}, u=10 \mathrm{~m} / \mathrm{s}$ and $n=52 \mathrm{~m}$, and Case (B) $s=4 \mathrm{~m}, u=6 \mathrm{~m} / \mathrm{s}$ or $8 \mathrm{~m} / \mathrm{s}, n=104 \mathrm{~m}$, varying the water drop area. Figures $17(\mathrm{C})$ and (D) show the fire spreading profiles of Case (A) at $t=3000 \mathrm{~s}$ and Case (B) at 3200s, respectively. The fire spread is protected by the water drop of Case A-(2) $W=8 \mathrm{~m} \times L=30 \mathrm{~m}$, Case A-(3) $W=8 \mathrm{~m} \times$ $L=52 \mathrm{~m}$, Case B-(2) $W=8 \mathrm{~m} \times L=80 \mathrm{~m}$, Case B-(4) $W=8 \mathrm{~m} \times L=104 \mathrm{~m}$. The fires at $s=3 \mathrm{~m}$ and $s=4 \mathrm{~m}$ do not jump over the water drop area and detour both sides of the water drop area. Therefore, if the spaces $(s)$ are much larger, much fewer water dropping can stop the fire spread.

(A)

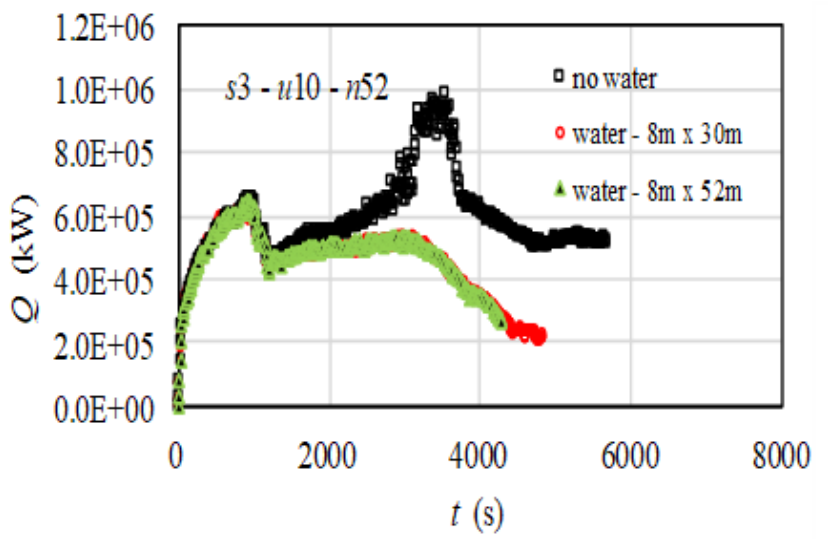

(B)

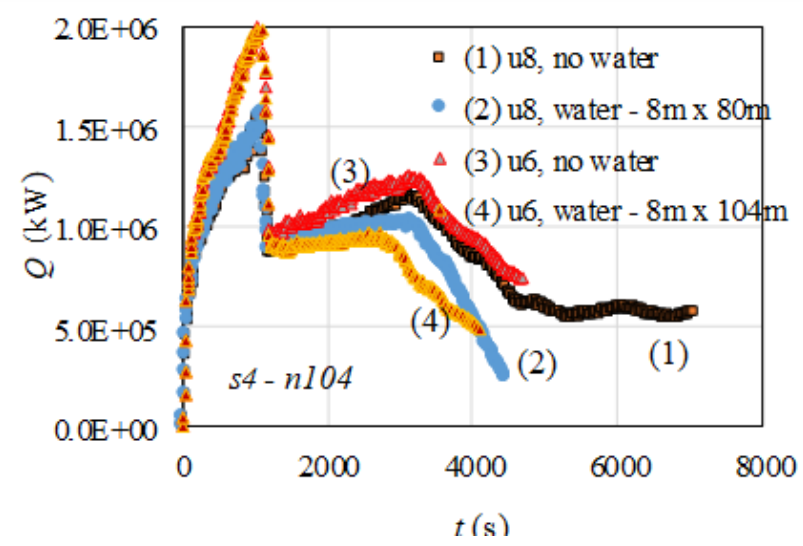


(C) Fire spreading patterns, $s=3 \mathrm{~m}, u=10 \mathrm{~m} / \mathrm{s}, n=52 \mathrm{~m}, t=3200 \mathrm{~s}$

(1) no water,

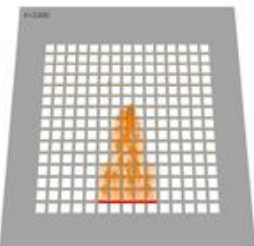

(2) water $-W=8 \mathrm{~m} \times L=30 \mathrm{~m}$,

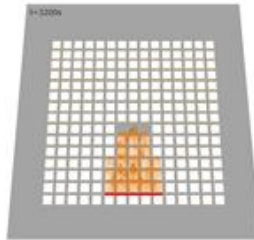

(3) water $-W=8 \mathrm{~m} \times L=52 \mathrm{~m}$

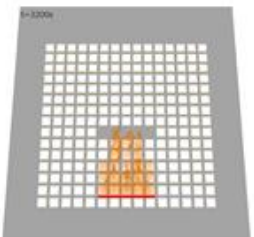

(D) Fire spreading patterns, $s=4 \mathrm{~m}, n=104 \mathrm{~m}, t=3000 \mathrm{~s}$

(1)-1

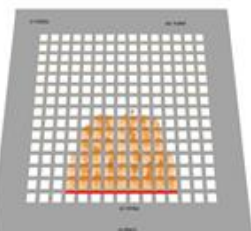

(1)-2

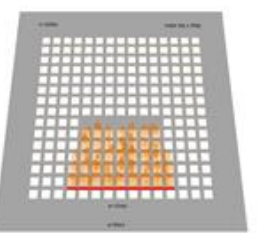

(2)-1

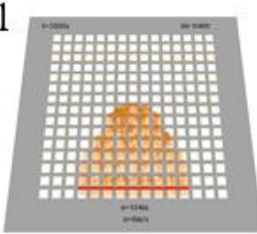

(2)-2

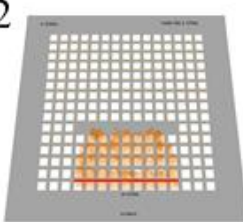

Figure 17 - (A) and (B): Relationship between heat release rate and time, varying water drop area, and $(C)$ and $(D)$ : Fire spreading patterns, varying the water drop area, (A) $s=3 \mathrm{~m}, u=10 \mathrm{~m} / \mathrm{s}, n=52 \mathrm{~m}, n=52 \mathrm{~m},(B) s=4 \mathrm{~m}, u=6 \mathrm{~m} / \mathrm{s}$ or $8 \mathrm{~m} / \mathrm{s}$, $n=104 \mathrm{~m},(C) s=3 \mathrm{~m}, u=10 \mathrm{~m} / \mathrm{s}, n=52 \mathrm{~m}, t=3200 \mathrm{~s},(D) s=4 \mathrm{~m}, n=104 \mathrm{~m}, t=3000 \mathrm{~s},(1)-1: u=8 \mathrm{~m} / \mathrm{s}$, no water, (1)-2: $u=8 \mathrm{~m} / \mathrm{s}$, water- $W=8 m \times L=80 m,(2)-1: u=6 m / s$, no water, (2)-2: $u=6 m / s$, water- $W=8 m \times L=80 m$.

\section{Discussion}

If the fuel distributes very densely like $s=0 \mathrm{~m}$, even the water belt dropped in the area of $20 \mathrm{~m} \times 60 \mathrm{~m}$ may not be sufficient to stop the fire spread perfectly, since fires may detour both sides of the water belt or jump over the water belt. To stop such fire spread, much larger water belt may be needed. If the fuels distribute discretely such as $s=3 \mathrm{~m}$ or $4 \mathrm{~m}$, the water belt of $20 \mathrm{~m}$ x $40 \mathrm{~m}$ may be able to stop the fire spread. However, helicopters carry only about 0.5 tons $=500 \mathrm{~kg}$ of water in the suspending bucket, but it is too few, since the water density on the ground is only $500 \mathrm{~kg} / 20 \mathrm{~m} / 40 \mathrm{~m}=0.6 \mathrm{~kg} / \mathrm{m}^{2}$ [7]. An aircraft carrying the water of 20tons can drop the water with the density of $25 \mathrm{~kg} / \mathrm{m}^{2}$ in the area of $20 \mathrm{~m} \times 40 \mathrm{~m}$, which is far better than those by helicopters. In this study, the selected way is to drop water in the downwind area slightly away from the fire front, eventually on a strongly burning area. It is dangerous for helicopter to fly in the hot and smoky sky, just above the fires. If helicopters fly at higher altitude and higher flight speed like larger aircrafts, it may be safe, but too few water drop may be disperse into mists in the sky. Therefore, large aircrafts carrying large amount of water, flying much higher altitude than helicopters, and passing through the smoke quickly above the burning fires, are needed to make such a large water belt. In the future, the water drop in an aerial firefighting may be done in much more effective ways based on the combination of the infrared reconnaissance of burning areas and the real-time CFD simulations of the burning profile of forest fires.

\section{Conclusion}

CFD simulations have been made to examine the effect of water dropped belt by an aerial firefighting to protect the fire spread. Some relationships are found, such as linear relationship between the heat release rate and the wind speed or the length of ignition heat source. The selected way in this study is to drop water in the downwind area slightly far from the fire front which may be more strongly burning place, making a water belt to reduce the radiative heat transfer to the fuels in the downwind area. However, if the fuel distributes densely, the water belt dropped in the area of $20 \mathrm{~m} \times 60 \mathrm{~m}$ may not be sufficient to stop the fire spread, since the fires may detour both sides of the water belt ort jump over the water belt. However, the water drops are very effective to delay the fire spreading speed. If 
the space distance between adjacent fuels is larger than $3 \mathrm{~m}$ or $4 \mathrm{~m}$, the water belt may be able to protect or extremely delay the fire spread. One problem is the amount of water to realize a water belt to protect the fire spread, since helicopters carry about 0.5 tons of water in the suspended buckets, which is too few and it is dangerous for helicopter to fly in the hot and smoky sky. If helicopters fly at higher altitude, it may be safe, but too few water drop may be disperse into mists in the sky. Large aircrafts carrying large amount of water such as 20tons are needed to make such a large water belt.

\section{References}

Viegas, D.X., , “A Mathematical Model For Forest Fires Blowup", Combustion Science and Technology, Vol. 177, pp.27-51, (2006)

Finney, M.A.,"Calculation of fire spread rates across random landscapes", International Journal of Wildland Fire, Vol.12, pp.167-174, (2003)

Abatzoglou, J.T., J. K. Balch, B. A. Bradley and C. A. Kolden, "Human-related ignitions concurrent with high winds promote large wildfires across the USA", International Journal of Wildland Fire, 27(6), pp.377-386, (2018)

Liu, N., Liu, Q., Deng, Z, Satoh, K., Zhu, J., "Burn-out time data analysis on interaction effects among multiple fires in fire arrays“, Proc. Comb. Inst., 31, pp. 2589-2597, (2007)

Satoh, K., S. Kitamura, K. Kuwahara, K.T.Yang, "An Analysis to Predict Forest Fire Danger and Fire Spread", ASME Proceedings of Heat Transfer, 2003 ASME Summer Heat Transfer Conference, Las Vegas, HT2003-47357, pp. 111-118 (2003)

Satoh K, K. Kuwahara, Yang K.T., "Experimental and Numerical Simulations of Flow Patterns of Dropping Water from Fire-fighting Helicopters", vol 5, ASME-HTD, Orlando, pp 57-64 (2000)

Satoh, K., Maeda, I., Kuwahara, K. and Yang, K.T., "A Numerical Study of Water Dump In Aerial Fire Fighting", IAFSS Fire Safety Science 8, Beijin, pp.777-787 (2005)

Satoh, K., N. Liu, Q. Liu, K.T.Yang, "Numerical and Experimental Study of Firewhirl Generated in 15x15 Array Fires Placed in Cross Wind", Proc. ASME 2008, Boston, pp.1-8, (2008)

McGrattan, K.B., Baum, H.R., Rehm, R.G., Hamins, A., and Forney, G.P., "Fire Dynamics Simulator: Technical Reference Guide," Technical Report NISTIR 6467, NIST, (2000).

Floyd, J., Forney, G., Hostikka, S., Korhonen, T., McDermott, R., and McGrattan, K., "Fire Dynamics Simulator User's Guide," NIST Special Publication 1019, NIST, (2006).

McGrattan, K.B., Floyd, J., Forney, G., Baum, H.R., Hostikka, S., "Development of Combustion and Radiation Models for Large Scale Fire Simulation," Proceedings of Third Technical Symposium on Computer Applications in Fire Protection Engineering, pp.2001-2011, (2001). 